\title{
Insulin and glucose in neonatal calves after peroral insulin and intravenous glucose administration *
}

\author{
R Grütter, JW Blum ** \\ Division of Nutrition Pathology, Institute of Animal Breeding, University of Berne, Switzerland
}

(Received 24 December 1990; accepted 22 March 1991)

\begin{abstract}
Summary - Effects of peroral insulin on plasma concentrations of immunoreactive insulin (IRI) and glucose in newborn calves were studied. Bovine insulin was administered in amounts of $0.5 \mathrm{mg} / \mathrm{kg}$ body weight immediately preceding first colostrum. Thereafter, neither an increased IRI response nor a lowering of blood glucose level were observed, indicating that insulin was either not absorbed from the intestine or possibly retained in the liver. Feeding of whole milk was followed by a higher rise in IRI and glucose concentrations than feeding of colostrum after po insulin. However, when compared with 1-3-month old calves, $|R|$ responses to feeding and to iv infused glucose were markedly smaller on the first and second day of life respectively, while glucose responses were similar. This indicates that insulin secretory mechanisms are not fully developed in the newborn calf.
\end{abstract}

insulin / glucose tolerance / neonate / calf

Résumé - Insuline et glucose chez le veau nouveau-né après administration orale d'insuline et perfusion Intraveineuse de glucose. Les effets de l'administration orale d'insuline sur les taux plasmatiques de linsuline et du glucose ont été étudiés chez le veau nouveau-né. Après l'administration d'insuline précédant immédiatement celle de colostrum, il n'a pas été observé de réponse d'insuline élevée ou de diminution du glucose; ceci indiquerait que l'insuline n'a pas été absorbée par l'intestin ou qu'elle a peut-être été retenue dans le foie. L'insuline et le glucose ont plus augmenté après l'ingestion de lait entier qu'après celle de colostrum. Par rapport à des veaux plus âgés, la réponse de l'insuline au repas ainsi qu'à la perfusion intraveineuse de glucose était nettement inférieure les 2 premiers jours de la vie, tandis que celle du glucose était semblable; ceci indiquerait que les mécanismes sécrétoires de linsuline chez le veau nouveau-né ne sont pas mis en place.

insuline / tolérance au glucose / nouveau-né / veau

\footnotetext{
* The data have been presented at the 23rd annual meeting of the American Society of Animal Science, August 6-9, 1991, Laramie, USA, and was published in abstract form in J Anim Sci 69, suppl 1 (1991) 455 (abstr 635)

** Correspondence and reprints
} 


\section{INTRODUCTION}

The physiology of digestion in the neonate is particular. Thus, in the newborn calf gastric acid secretion is considerably less than in the adult (Pierce et al, 1964). Ingested proteins may therefore largely be prevented from degradation. Additionally, the abomasum of preruminant calves selects proteins and peptides that are released to the small intestine. Thus the major part of whey proteins, but not casein, is evacuated rapidly without proteolysis (Yvon et al, 1986). Furthermore, during the first hours after birth, high molecular weight proteins, such as immunoglobulins, pass directly through the "open" gut into the circulation of calves. At birth umbilical blood supply is interrupted and nutrients are transported to the liver by the portal vein. However, part of the nutrients absorbed by the digestive tract as well as pancreatic hormones flowing into the portal vein may by-pass the liver and reach the general circulation directly through the arterial canal, which is not suddenly occluded (Botti et al, 1982).

There are high amounts of insulin in bovine colostrum (Ballard et al, 1982; Slebodzinski et al, 1986; Malven et al, 1987; Ronge and Blum, 1988; Collier et al, 1989; Wahab et al, 1989; Grütter and Blum, unpublished data), which rapidly decrease to the low levels present in milk during later stages of lactation. However, only few investigations have been carried out on insulin in newborn calves (Young et al, 1970; Breier et al, 1988; Ronge and Blum, 1988; Oda et al, 1989). Pierce et al (1964) found increased bioactive serum insulin and a lowering of blood glucose levels after po administration of high amounts of bovine insulin to newborn calves, suggesting that insulin may be absorbed from the gut of the newborn calf.
The primary objective of our investigations was to study effects of po administered insulin preceding feeding of first colostrum, in comparison with feeding of whole milk, on plasma concentrations of immunoreactive insulin (IRI) and glucose in newborn calves. In addition, responses of $|R|$ and glucose to iv infused glucose were studied in blood plasma of 2-d-old calves compared with older calves.

\section{MATERIALS AND METHODS}

\section{Experimental procedures}

\section{Experiment 1}

Eight eutocic newborn calves (2 males and 6 females; 4 Simmental crossbreds (SiRH), 3 Swiss Brown (SB) and $1 \mathrm{SB} \times \mathrm{SiRH}$ ) were studied. They were born at term and received their first meal (maternal colostrum) in the morning (between 08.15 and $09.00 \mathrm{~h}$ ), at $4.5 \mathrm{~h}(\mathrm{~h})$ after birth (average). Thereafter, until the end of the experiments colostrum in amounts of $\approx 5 \%$ of body weight (BW) was offered twice daily (between 05.30 and $07.30 \mathrm{~h}, 16.00$ and $18.00 \mathrm{~h}$ ). Calves were po given $0.5 \mathrm{mg}$ insulin $/ \mathrm{kg} \mathrm{BW}$ immediately preceding the first colostrum (5\%--one calf $4 \%$ - of BW). Bovine insulin was obtained from Sigma Chemical Company, St Louis, MO, USA (No 1-5500). Activities ranged from 23.4-26.8 IU/mg. Insulin was dissolved $(1: 1000)$ in $0.9 \%$ saline containing $0.1 \%$ bovine gammaglobulin (final $\mathrm{pH} 7.4$ ).

Three additional eutocic newborn calves (males, SiRH) served as controls. They were born at term and received their first meal in the morning (between 07.45 and $08.30 \mathrm{~h}$ ), at $5.5 \mathrm{~h}$ after birth (average). They were given whole milk in amounts of $5 \%$ of their BW during the first 2 feedings, while the first colostrum was preserved in a refrigerator up to the third meal $15 \%$ of BW). After the first meal, time of feedings was similar to that of group $A$.

Blood samples $(10 \mathrm{ml}, \mathrm{A}$; or $40 \mathrm{ml}, B)$ of these calves were taken at $0.25 \mathrm{~h}$ before and at 
$0.25,0.5,0.75,1,1.25,1.5,1.75,2.2 .5,3,8 \mathrm{~h}$ after the first meal. In group $A$, additional blood samples were taken at $3.5,4,5,6$, and $7 \mathrm{~h}$ after the first meal.

\section{Experiment 2}

On the second day (d) of life, starting at $10.00 \mathrm{~h}$, an iv glucose tolerance test was performed: $0.33 \mathrm{~g}$ glucose $/ \mathrm{kg}^{0.75} \mathrm{BW} \times$ min was infused for 5 min in 7 of the 8 calves.

Ten 1-3-month-old milk-fed male or female calves (SB or Red Holstein) served as controls. They received milk in amounts of 3-7 I between 07.00 and $08.00 \mathrm{~h}$. Calves were iv infused with $0.33 \mathrm{~g} / \mathrm{kg}^{0.75} \mathrm{BW} \times \min$ for $5 \mathrm{~min}$, starting at $6 \mathrm{~h}$ atter feeding.

Blood samples $(10 \mathrm{ml})$ from these calves were taken immediately before and at $5,10,15$, $20,30,45,60 \mathrm{~min}$ after the start of infusion.

Blood samples were taken from the external jugular vein, either with vacutainers containing lithium heparin (Monoject, Sherwood Medical, St Louis, MO, USA) (exp 1) or through indwelling catheters, implanted in calves prior to the first feeding $(\exp 2 \mathrm{~A})$, on the evening before the experiment $(\exp 2 B)$. Blood from catheters was transferred to polystyrene tubes containing lithium heparin (HEP-95, Milian Instruments SA, $\mathrm{CH}-1228$ Plan-les-Ouates/Geneva). Tubes were centrifuged at $1500 \mathrm{~g}$ and $4^{\circ} \mathrm{C}$ for $15 \mathrm{~min}$. Plasma was then partitioned into aliquots of $\approx 1.5 \mathrm{ml}$ and stored in polypropylene microtubes (Milian, Geneva) at $-18{ }^{\circ} \mathrm{C}$ until analyzed for IRI and glucose.

All animals were held at the Federal Research Station for Animal Production, Grangeneuve/CH-1725 Posieux.

\section{Laboratory methods}

Blood plasma concentrations of IRI and glucose were measured as recently described (Zimmerli and Blum, 1990).

\section{Statistical analysis}

Data are expressed as means \pm SEM. Total responses of $I R I$ and glucose were evaluated by calculation of areas under concentration curves after subtraction of (mean) basal levels ( $\triangle 0-3 \mathrm{~h}$ and $\Delta 0-8 \mathrm{~h}$, without consideration of values at $4,5,6$ and $7 \mathrm{~h} ; \Delta 0-60 \mathrm{~min}$, respectively). Halftime $\left(T_{1 / 2}\right)$ and clearance rate $(k)$ of glucose in iv glucose tolerance tests were calculated according to Kaneko (1980). The significance of changes after treatments within groups was evaluated by Wilcoxon Signed Ranks test. The significance of differences between groups (net changes $(\Delta)$ of single values and total responses) was evaluated by the Mann-Whitney $U$ test, using the SYSTAT program (SYSTAT Inc, Evanston, IL, USA). In exp 1, Pearson's correlation coefficient between total responses of IRI and glucose $(\triangle 0-8)$ was computed using the SAS program (SAS Institute Inc, Cary, NC, USA).

\section{RESULTS}

\section{Concentrations of IRI and glucose in newborn calves after peroral administration of insulin or ingestion of whole milk (exp 1, fig 1)}

Concentration of $|R|$ and glucose increased significantly after po administration of insulin, which immediately preceded first colostrum intake $(P \leq 0.05)$. In calves fed whole milk (but no additional insulin), increases of $|R|$ and glucose concentrations were much more pronounced than in calves fed insulin preceding colostrum. Changes $(\Delta)$ in glucose concentration at $1.5,1.75,2,2.5$ and $3 \mathrm{~h}$ were significantly smaller in calves fed insulin preceding colostrum than in calves fed whole milk ( $P \leq$ $0.05)$. Likewise, total responses of $|R|(\Delta$ $0-8 \mathrm{~h}$ ) and glucose ( $\Delta 0-3 \mathrm{~h}$ and $\Delta 0-8 \mathrm{~h}$ ) respectively were significantly smaller in calves fed insulin preceding colostrum than in calves fed whole milk $(P \leq 0.05)$. There was a positive correlation between total responses of IRI and glucose $(\Delta 0-8$ h) in calves fed colostrum or whole milk $(r=0.56 ; P=0.07)$. 

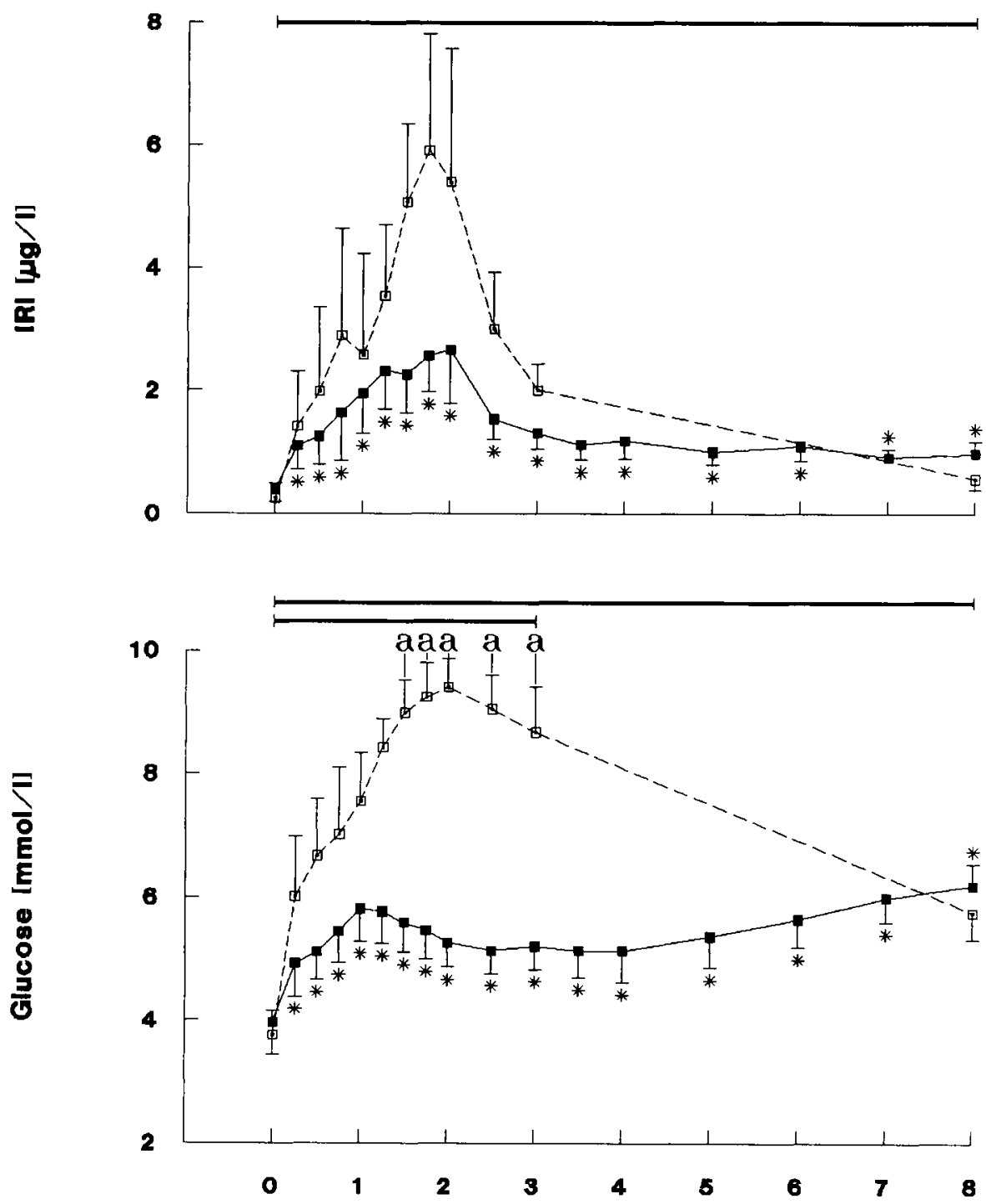

Time after feeding [h]

Fig 1. Plasma concentrations of insulin and glucose in newborn calves before $(0 \mathrm{~h})$ and for $8 \mathrm{~h}$ after either the po administration of $0.5 \mathrm{mg}$ insulin $/ \mathrm{kg} \mathrm{BW}$ preceding the ingestion of first colostrum (-, filled symbols) or the ingestion of whole milk $(---$, open symbols). " Significantly $(P \leq 0.05)$ different from basal level $(0 \mathrm{~h})$; a significantly $(P \leq 0.05)$ different from response to feeding of whole milk; significantly $(P \leq 0.05)$ different total responses $(\Delta 0-3 \mathrm{~h}, \Delta 0-8 \mathrm{~h})$ beiween calves fed colostrum and those fed whole milk (without consideration of values at $4,5,6$ and $7 \mathrm{~h}$ ). 


\section{Effects of intravenous glucose on concentrations of IRI and glucose in calves on the second day of life or at the age fo $1-3$ months (exp 2, fig 2)}

Basal concentrations of IRI were $0.68 \pm$ 0.14 and $0.36 \pm 0.06 \mu \mathrm{g} / \mathrm{l}$ in 2-d-old and older calves, respectively. Concentration of IRI increased immediately after the start of the infusion and peaked at $20 \mathrm{~min}$ in both 2-d-old and older calves. All values were significantly higher than basal levels $(P \leq$ $0.05)$. Changes in IRI concentration $(\Delta)$ were consistently smaller in 2-d-old than in older calves $(P \leq 0.05$ at $30 \mathrm{~min}$ and $P \leq$ 0.1 at 5 and $45 \mathrm{~min}$ ). Total IRI response ( $\Delta$ $0-60 \mathrm{~min}$ ) tended to be smaller in 2-d-old than in older calves $(P=0.051)$.

Basal concentration of glucose was significantly higher in 2-d-old than in older calves $(8.02 \pm 0.29$ and $4.67 \pm 0.13 \mathrm{mmol} /$ $\mathrm{I}$, respectivey; $P \leq 0.001)$. Glucose concentration increased sharply after the start of the infusion and was highest at $5 \mathrm{~min}$ in both 2-d-old and older calves. Thereafter, glucose concentration decreased in a similar manner in 2-d-old and older calves $\left(T_{1 / 2}\right.$ $=31.2$ and $29.5 \mathrm{~min} ; k$ values $=2.2$ and $2.5 \% / \mathrm{min}$ respectively) and almost reached basal levels after $60 \mathrm{~min}$. Values from 5-45 $\mathrm{min}$ were significantly higher than basal levels $(P \leq 0.05)$. Changes in glucose concentration $(\Delta)$ tended to be smaller at $10 \mathrm{~min}$, but higher at $60 \mathrm{~min}$ in 2 -d-old than in older calves $(P \leq 0.1)$.

\section{DISCUSSION}

Pierce et al (1964) found increased bioactive serum insulin and a lowering of blood glucose levels after po administration of bovine insulin to newborn calves, especial- ly if administered in alkaline solution. Contrary to our study, glucose was usually fed prior to insulin administration. In addition, insulin-like activity was determined by an indirect biological method and not radioimmunologically as in our study. As in neonatal calves, serum concentrations of colostral small proteins increased more rapidly after the first feeding than those of IgG (Kiriyama et al, 1989), a similar rapid increase of plasma IRI levels was expected in our calves, also. In contrast, neither an increased $|R|$ response nor a lowering of blood glucose level were observed after po administration of comparably excessive amounts of insulin $(\approx 500$ times the quantity which was measured in 21 of first colostrum; Grütter and Blum, unpublished data) preceding first colostrum. The reasons for the discrepancy between our data and those of Pierce et al (1964) are not clear. Feeding of colostrum, which immediately followed insulin administration, may have prevented insulin from absorption by inclusion in the food matrix. However, in 3 unfed newborn calves (not shown), administration of insulin in buffered solution alone or together with lactose did not influence plasma concentrations of IRI and glucose. This, too, was not the case, if insulin administration was immediately preceded by the injection of lysine-vasopressin, shown to facilitate contraction of the oesophageal groove in cattle (Scholz and Mikhail, 1987; van Weeren-Keverling Buisman et al, 1990), thus favouring a direct passage of ingested insulin into the abomasum. Whether uptake by the liver during the first passage possibly prevents absorbed insulin from appearance in the peripheral blood still requires investigation.

Amounts of lactose were considerably lower in first colostrum than in pooled milk (morning/evening) taken on the 7 th or 12 th 

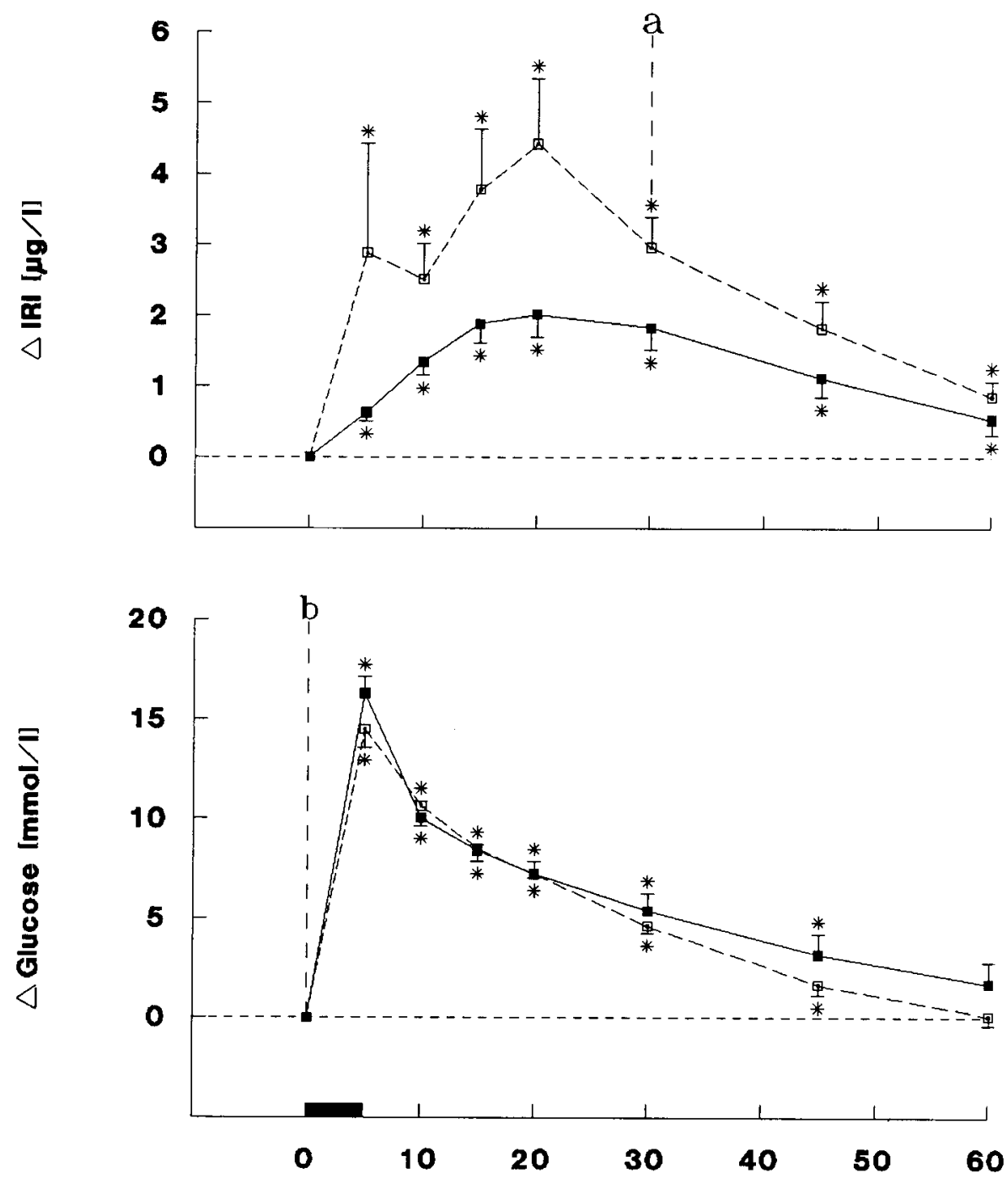

\section{TIme after the start of glucose infusion [min]}

Fig 2. Intravenous glucose tolerance test: changes in plasma concentrations $(\Delta)$ of insulin and glucose in calves before $\left(0 \mathrm{~min}\right.$ ) and for $60 \mathrm{~min}$ after the start of glucose infusion $\left(-; 0.33 \mathrm{~g} / \mathrm{kg}^{0.75} \mathrm{BW} \times\right.$ $\mathrm{min}$ for $5 \mathrm{~min}$ ) on the 2 nd day of life (-, filled symbols) or at 1-3 months of age $(---$, open symbols). " Significantly $(P \leq 0.05)$ different from basal level; a significantly $(P \leq 0.05)$ different from response in 1-3-month old calves; b significantly $(P \leq 0.001)$ different from basal level in $1-3$-month-old calves. 
d after parturition ( $35.3 \pm 2.0$ vs $49.2 \pm 1.0$ g/l) (not shown). Therefore, the significantly higher responses of IRI and glucose to feeding of whole milk when compared with colostrum after po insulin were probably due to the higher lactose content of whole milk. Thus, the higher rise in blood glucose level after ingestion of whole milk may have caused the increased IRI response. In agreement, we found a positive correlation between postprandial responses of IRI and glucose in newborn calves fed colostrum or whole milk. On the other hand, the lower $\mathbf{I R I}$ response in calves fed colostrum following po insulin than in those fed whole milk could reflect suppression of endogenous insulin secretion by ingested exogenous insulin or other colostrum constituents. Thus, insulin-like growth factor I, which is present in colostrum in high amounts (Francis et al, 1986; Ballard et al, 1987; Malven et al, 1987; Francis et al, 1988; Ronge and Blum, 1988; Campbell and Baumrucker, 1989; Collier et al, 1989; Oda et al, 1989; Vega et al, 1989; Grütter and Blum, unpublished data), was shown to inhibit insulin secretion in man (Guler et al, 1989). However, it remains to be clearly demonstrated that insulin-like growth factor I can be absorbed from gut of the newborn calf as a precondition to suppress insulin secretion. Alternatively, other blood glucose regulating hormones, such as glucagon, glucocorticoids and catecholamines could have been released in different amounts in response to the ingestion of first colostrum following po insulin or whole milk and, in consequence, could have influenced postprandial blood glucose and IRI levels.

Plasma insulin level in $\approx 3$-month-old milk-fed calves rose to $16 \mu \mathrm{g} / \mathrm{l}$ after feeding (Kamalu and Trenkle, 1978). At the same time, a high plasma glucose concentration was measured. Feeding of whole milk was followed by an increase of blood glucose in the range of that observed by Kamalu and Trenkle (1978) in our newborn calves too, but IRI concentration only rose to $5.92 \mu \mathrm{g} /$, which is also considerably less than what was observed in 2-3-month-old milk-fed calves (Zimmerli and Blum, 1990). This indicates that insulin secretory mechanisms are not fully developed in the newborn calf.

The duration of insulin-induced hypoglycaemia in calves was prolonged immediately after birth, indicating that the factors normalizing blood glucose concentration are not very efficient at this time (Comline and Edwards, 1968). Therefore in the newborn the sensitivity of the liver to insulin may be low (Demigné and Rémésy, 1984). In our study, the IRI response to iv glucose was markedly smaller in 2-d-old than in older calves, whereas changes in glucose concentrations were similar in both groups. Glucose utilization is known to decrease with age (Young et al, 1970), mainly as a result of transition from non-ruminant to ruminant metabolism. However, it remains to be shown whether different utilization rates in 2-d-old to those in 1-3-month-old calves could have significantly influenced our data. Higher basal levels of blood glucose in 2-d-old than in older calves might, in addition, be due to differing time relative to feeding.

\section{CONCLUSION}

In conclusion, the results suggest that exogenous insulin ingested with maternal colostrum may not substantially contribute to circulating IRI levels, for it did not appear to be absorbed from the gut or, if absorbed, obviously did not reach the general circulation in significant amounts. In addition, insulin secretory mechanisms do not seem to be fully developed in the newborn calf. 


\section{REFERENCES}

Ballard FJ, Nield MK, Francis GL, Dahlenburg GW, Wallace JC (1982) The relationship between the insulin content and inhibitory effects of bovine colostrum on protein breakdown in cultured cells. J Cell Physiol 110, 249-254

Ballard FJ, Francis GL, Ross $M$, Bagley CJ, May B, Wallace JC (1987) Natural and synthetic forms of insulin-like growth factor-1 (IGF-1) and the potent derivate, destripeptide IGF-1: biological activities and receptor binding. Biochem Biophys Res Commun $149,398-404$

Botti JJ, Edelstone DI, Caritis SN, MuellerHeubach E (1982) Portal venous blood flow distribution to liver and ductus venosus in newborn lambs. Am J Obstet Gynecol 144, 303-308

Breier BH, Gluckman PD, Bass JJ (1988) Plasma concentrations of insulin-like growth factor-I and insulin in the infant calf: ontogeny and influence of altered nutrition. J Endocrinol 119, 43-50

Campbell PG, Baumrucker CR (1989) Insulinlike growth factor-l and its association with binding proteins in bovine milk. $J$ Endocrinol $120,21-29$

Collier RJ, Ganguli S, Menke PT, Buonomo FC, McGrath MF, Kotts CE, Krivi GG (1989) Changes in insulin and somatomedin receptors and uptake of insulin, IGF-I and IGF-II during mammary growth, lactogenesis and lactation. In: Biotechnology in Growth Regulation (Heap RB, Prosser CG, Lamming GE, eds) Butterworth \& Co, London, 153-163

Comline RS, Edwards AV (1968) The effect of insulin on the new-born calf. J Physiol 198, 383-404

Demigné C, Rémésy C (1984) Métabolisme foetal et post-natal chez le veau et l'agneau. In: Physiologie et Pathologie Périnatales Chez les Animaux de Ferme (Jarrige R, ed) INRA, Paris, 189-202

Francis GL, Read LC, Ballard FJ, Bagley CJ, Upton FM, Gravestock PM, Wallace JC (1986) Purification and partial sequence analysis of insulin-like growth factor- 1 from bovine colostrum. Biochem J 233, 207-213
Francis GL, Upton FM, Ballard FJ, McNeil KA, Wallace JC (1988) Insulin-like growth factors 1 and 2 in bovine colostrum. Biochem $J 251$, 95-103

Guler HP, Schmid C, Zapf J, Froesch ER (1989) Effect of recombinant insulin-like growth factor I on insulin secretion and renal function in normal human subjects. Proc Natl Acad Sci USA 86, 2868-2872

Kamalu TN, Trenkle AH (1978) Postprandial changes in plasma insulin, plasma glucose, and plasma free fatty acids of milk-fed calves. Nutr Rep Int 18, 243-148

Kaneko JJ (1980) Carbohydrate metabolism and its disorders. In: Clinical Biochemistry of Domestic Animals (Kaneko JJ, ed) Academic Press, NY, 1-51

Kiriyama $H$, Harada $E$, Syuto $B(1989)$ Analysis of colostral proteins in calf serum by enzymelinked immunosorbent assay. J Dairy Sci 72 , 398-406

Malven PV, Head HH, Collier RJ, Buonomo FC (1987) Periparturient changes in secretion and mammary uptake of insulin and in concentrations of insulin and insulin-like growth factors in milk of dairy cows. J Dairy Sci 70 , 2254-2265

Oda S, Satoh H, Sugawara T, Matsunaga N, Kuhara T, Katoh K, Shoji Y, Nihei A, Ohta M, Sasaki $Y$ (1989) insulin-like growth factor-I, $\mathrm{GH}$, insulin and glucagon concentrations in bovine colostrum and in plasma of dairy cows and neonatal calves around parturition. Comp Biochem Physiol 94, 805-808

Pierce AE, Risdall PC, Shaw B (1964) Absorption of orally administered insulin by the newly born calf. J Physiol 171, 203-215

Ronge $\mathrm{H}$, Blum JW (1988) Somatomedin C and other hormones in dairy cows around parturition, in newborn calves and in milk. J Anim Physiol Anim Nutr 60, 168-176

Scholz H, Mikhail M (1987) Untersuchungen zur Nutzung der Schlundrinnenkontraktion in der Behandlung innerer Erkrankungen des Rindes. 1. Mitteilung: Auslösbarkeit der Schlundrinnenkontraktion durch intravenöse Verabreichung von Vasopressin. Tieräerztl Umsch 42, 280-287

Slebodzinski AB, Nowak J, Gawecka $H$, Sechman A (1986) Thyroid hormones and insulin 
in milk; a comparative study. Endocrinol Exp 20, 247-255

Vega JR, Gibson CA, Baumrucker CR (1989) Insulin-like growth factor-I (IGF-I) in mammary secretions of prepartum dairy cows. J Anim Sci 67 (suppl 1); J Dairy Sci 72 (suppl 1), 194

Wahab IM, Anderson RR, Ireland F, Loch W (1989) Periparturient changes in immunoreactive insulin (IRI) concentrations of bovine, equine and ovine colostrum, milk and blood serum. J Anim Sci 67 (suppl 1); J Dairy Sci 72 (suppl 1), 313

van Weeren-Keverling Buisman $A$, Kuiper $R$, Wensing T, Breukink HJ (1990) The effect of vasopressin on the closure of the reticular groove in the veal calf. J Anim Physiol Anim Nutr 64, 240-249

Young JW, Otchere EO, Trenkle A, Jacobson NL (1970) Effect of age on glucose, reducing sugars and plasma insulin in blood of milkfed calves. J Nutr 100, 1267-1273

Yvon M, Pélissier JP, Guilloteau P, Toullec R (1986) Digestion des protéines du lait dans la caillette du veau préruminant. Reprod Nutr Dév 26, 705-715

Zimmerli UV, Blum JW (1990) Acute and longterm metabolic, endocrine, respiratory, cardiac and skeletal muscle activity changes in response to perorally administered $\beta$ adrenoceptor agonists in calves. J Anim Physiol Anim Nutr 63, 157-172 